\title{
Charting new territory
}

\section{Santa Clara, California}

A 15-member delegation of Soviet science officials met members of the US high-technology industry in Silicon Valley last week as part of the first Soviet Silicon Summit, a conference held to establish science agreements between the two countries.

For US participants, the message from the Soviet delegation was simple: Soviet science is better than its reputation suggests but Soviet scientists need help to commercialize their inventions.

Unfortunately, Soviet scientists do not have the hard currency to pay for the help they need. They are, however, willing to sign barter agreements. "We are great people, but we're out of luck and we have to correct our mistakes", said Nicolai Kleschev, director of the International Center for Informatics and Electronics.

As part of planned Soviet free-market reforms, 2,000-3,000 technical cooperatives, or small laboratories, will become part of the private sector in July. That means that government subsidies are likely to be reduced or abandoned and the centres will have to earn their own keep, either by licensing their technology or by using it to create products. To succeed, the laboratories need Western technology, especially computers and semiconductor production tools. But without hard cash, they can offer only basic research, collaboratorations and commodities that are not in short supply.

For US companies, the idea of barter is new. Goodwill towards the Soviet Union is in good supply, but concern for the bottom line makes 'non-traditional payment' difficult. Adept Technology, a Silicon Valley robotics company, recently turned down an offer to trade 500 robots for a shipment of caviar and vodka.

Nevertheless, by the end of the summit, Soviet scientists had claimed some trading successes, albeit in more traditional veins.

A unique deal was signed with Cypress Semiconductor Corporation to manufacture Soviet-designed high-definition television and signal-processing chips in the United States. Cypress will pay fees to the Soviet Union on sales of the chips, which the company says could amount to $\$ 60$ million per year.

Other agreements are expected. Although the commercial microelectronics industry in the Soviet Union is far behind that in the West, some basic semiconductor research supported by military funds has kept pace. Soviet laboratories had 1-megabit DRAM chips in limited production before US companies first produced their initial runs of the chips in 1986. Soviet scientists claim to be ahead in certain cyclotron techniques for the fabrication of submicrometre semiconductors, some laser technologies, X-ray optics, ion sources and laser interferometry. "Patent searches were done and no similar developments were found in the West", says Kamil Valiev of the Institute of Physics and Technology.

Almost all the technologies are for sale but US buyers are cautious. "You have to feel a little sceptical", says Nicholas Gralenski, staff scientist for Watkins-Johnson, a California high-technology company. "If the Soviet economy is so weak, how can their technology be strong?" Like many other participants at the conference, he admits that he is more interested in the Soviet Union as a market than as a research partner.

There are between 600,000 and 800,000 IBM-compatible personal computers in the Soviet Union, well behind the 1.1 million that the Soviet five-year plan says should be installed by now.

Atari Corporation is negotiating an arrangement to ship home computers to the Soviet Union in exchange for Sovietmade $256 \mathrm{~K}$ memory chips. And Soviet officials at last week's meeting suggested that US companies could capitalize on the Soviet Union's traditional strengths in mathematical and theoretical sciences. When supplied with modern computers, Soviet scientists have produced impressive software. Soviet officials ask: why not ship computers to Soviet laboratories and get software back in return?

Although the Soviet scientists at the summit were new to the art of the deal, they made it clear they would avoid earlier mistakes. Bausch and Lomb made a fortune from a soft contact-lens polymer that came from the Czechoslovakian Academy of Science in the 1960 s, but the Czech government took most of the onetime license fee and the original laboratory received little in return. When Bausch and Lomb recently licensed a natural collagen corneal shield from the Moscow Institute for Eye Microsurgery, it found a new awareness of market savvy. The shield agreement sets royalties based on sales, rather than a single fee, and a sizeable percentage of the money will return to the institute.

As free-market reforms pass financial responsibility to individual laboratories, more will demand full proceeds from their patents, says Gordon Feller, editor of the East-West Report, a US-Soviet trade newsletter. "There is still a fogginess about data ownership", he says, "Who owns the patent? The inventor, the laboratory, or the government?" Ambiguity on that issue has led at least one Soviet laboratory to ask a Western company to sign a confidentiality agreement on an agreement so the laboratory would not have to share the proceeds with its ministry. "The legal structure and framework in the Soviet Union is changing as we speak," said Jeffrey Armstrong of Global Development Corporation, which sponsored the conference. "The rules are written by virtue of the deals that get done."

G. Christopher Anderson

\section{Still some life in the 'pro-lifers'}

\section{London}

As the Human Fertilisation and Embryology Bill nears the end of its stormy passage through parliament, the UK government is being accused by Dame Mary Donaldson, chairman of the Interim Licensing Authority (ILA) which currently oversees embryo research, of giving "undue weight" to the views of a minority of 'pro-life' Members of Parliament (MPs), in its plans to set up a statutory authority to replace the ILA. Donaldson fears that the new authority will lack the experience necessary to make informed judgements on whether to grant licences for research.

The ILA was set up by the Medical Research Council and the Royal College of Obstetricians and Gynaecologists in the wake of the 1984 Warnock Report on human embryology (on which the bill is broadly based), to provide a voluntary framework of licensing for scientists involved in embryo research, and clinics offering in vitro fertilization (IVF) services.

Donaldson attacked the government's plan to set up a separate "embryonic" statutory authority to work alongside the ILA. The statutory authority will take over full responsibility for licensing embryo research and IVF by the summer of 1991 . For the sake of continuity and to use ILA's experience, she said it would be better for the ILA to evolve into a statutory body by the gradual replacement of its members with government appointees.

The ILA has a majority of members from a scientific or medical background. MPs opposed to embryo research say the ILA is biased in favour of research, and do not want it to be given statutory powers for licensing under the bill. For the sake of a "quiet life", Donaldson said, the government had given in to this minority of MPs.

But one MP, who sat on the House of Commons committee which has debated the bill and voted in favour of continued embryo research in the recent Commons vote, says that there is "a strong lobby of opinion" among MPs, backing the government's plans to set up a separate authority. The bill states that the new authority must have a lay chairman and deputy chairman, and less than half of its members must be medical practitioners or have been involved with embryo research or IVF.

Peter Aldhous 